medRxiv preprint doi: https://doi.org/10.1101/2021.05.11.21256630; this version posted May 11, 2021. The copyright holder for this preprint

(which was not certified by peer review) is the author/funder, who has granted medRxiv a license to display the preprint in perpetuity.

All rights reserved. No reuse allowed without permission.

\title{
Prediction of blood Sugar Regulation based on Healthy Boundaries, Ego \\ Boundary and Post-trauma Growth in Patients with Diabetes.
}

\section{Masoumeh Abrandabadi}

MA Student, Department of psychology, UAE Branch, Islamic Azad University, Dubai, United Arab Emirates

Abrand55@gmail.com

\section{Dr Maryam Mashayekh (corresponding author)}

Assistant Professor, Department of psychology, Karaj Branch, Islamic Azad University, Karaj, Iran

$$
\text { m.mashayekh@kiau.ac.ir }
$$

\section{Abstract}

Aims: The aim of this study was prediction of blood sugar regulation based on ego boundary, healthy boundary and post trauma growth in patient with Diabetes.

Methods: For this purpose, 50 people with diabetes were selected by multistage cluster sampling. The questionnaires used in this study were the post trauma growth inventory (PGI), the ego strength (PIES), and Healthy Boundaries (HB) Questionnaire.

Results: Stepwise regression analysis showed that there were a significant positive relationship between blood sugar level (HbA1c) and ego strength, health boundaries and post-trauma growth (PTG).

Conclusion: The findings indicate a significant correlation between hyperglycemia and health boundaries, ego strength and post-traumatic growth. This means that controlling and recognizing the boundaries of mental health and post-traumatic emotions prevents high blood (HbA1c) sugar and Type 2 diabetes.

Keywords: Blood Sugar Regulation, HbA1c, Type II Diabetes, post-trauma growth, Healthy Boundaries, Ego Boundaries, Ego strength. 
medRxiv preprint doi: https://doi.org/10.1101/2021.05.11.21256630; this version posted May 11, 2021. The copyright holder for this preprint

(which was not certified by peer review) is the author/funder, who has granted medRxiv a license to display the preprint in perpetuity.

All rights reserved. No reuse allowed without permission.

\section{Introduction}

Diabetes is a chronic disease that physiological, cognitive, behavioral, emotional and social factors play a role in preventing, risk and regulating it and considered the epidemic of the twentyfirst century. Diabetes is a huge healthcare burden worldwide. There is substantial evidence that lifestyle modifications and drug intervention can prevent diabetes, therefore, an early identification of high risk individuals is important to design targeted prevention strategies. (Hasan T. Abbas. et al, 2019)

In 2019, it is estimated that 4.2 million adults aged 20-79 years will die from diabetes, accounting for $11.3 \%$ of deaths from all causes. This is equivalent to eight deaths every minute. Almost half of these deaths $(46.2 \%, 1.9$ million) are estimated to occur in adults younger than 60 years. (Saeedi, at el 2020)

The prevalence of diabetes, chiefly Type 2 Diabetes Mellitus (T2DM), is particularly high in Iran. Few studies have been undertaken to psychosocially reviewpreventofT2DM.

Diabetes is an expensive medical problem in Iran and planning of national programmers for its control and prevention is necessary. The rates of T2DM are increasing.

It is associated with significant complications and a high cost of treatment, especially when glycemic control is poor. Despite its negative impact on health, data is still lacking on the possible biopsychosocial predictors of poor glycemic control among the diabetic population.(Sy-Cherng woon, at el 2020)

Diabetes and psychiatric disorders share a bidirectional association influencing one another in multiple ways and different patterns, like depression, anxiety, etc. (Balhara 2011)

Cognitive theories of depression have long held that the tendency to appraise stressful events in an irrational or distorted manner predisposes an individual to experience emotional and behavioral dysfunction (Beck, 1967; Haaga, Dyck, \& Ernst, 1991). Cognitive theorists typically describe distorted cognitions as appraisals or conclusions mat reflect a bias in the processing of information or that are inconsistent with some commonly accepted views of reality (Alloy\& Abramson, 1988; Beck, 1967). Recent evidence suggests that distorted appraisals may result in increased behavioral disability or dysfunction among physically ill individuals as well as in dysphoric mood (Christensen et al., in press; Flor\& Turk, 1988; Smith, Follick, Ahern, \& Adams, 1986; Smith, Peck, Milano, \& Ward, 1988)

Depression and anxiety are common psychiatric complications affecting patients with diabetes mellitus. However, data on the prevalence of depression, anxiety, and associated factors among 
medRxiv preprint doi: https://doi.org/10.1101/2021.05.11.21256630; this version posted May 11, 2021. The copyright holder for this preprint (which was not certified by peer review) is the author/funder, who has granted medRxiv a license to display the preprint in perpetuity. All rights reserved. No reuse allowed without permission.

Malaysian diabetic patients is scarce. The Anxiety, Depression, and Personality Traits in Diabetes Mellitus (ADAPT-DM) study aimed to determine the prevalence of depression and anxiety, and their associated factors in the Malaysian diabetic population. (Sy-Cherng Wood, at el 2020)

There is another study, Positive Psychological Interventions for Patients with Type 2 Diabetes: Rationale, Theoretical Model, and Intervention Development. (Jeff C. Huffman. et al, 2015) Based on the findings of previous study, we can say that by identifying the health locus of control and irrational health beliefs, it is possible that blood glucose level can be predicted in patients with Type II diabetes and reduced the Consequences of diabetes in people with it. (fathabadi.et al., 2018), so the main question of this research: Does blood Sugar Regulation predict on based of Healthy Boundaries, Ego Boundary and Post-trauma Growth in Patients with Diabetes?

\section{METHODS}

The present study was descriptive in terms of collection and applied in terms of purpose.

Statistical Society: In the present study, 50 randomly selected multistage clusters were selected from all patients with Type 2 diabetes who referred to diabetes treatment centers such as Taban Diabetes Clinic and Diabetes Association in Tehran in 1398. One year from the diagnosis of the disease. In the past, they had no other disease than diabetes, and they were over 25 years old, according to entry criteria. A list of more than 100 diabetics was compiled from the statistical population. The method of estimating the sample size is the Cochran's formula.

\section{Research tools}

The questionnaires used in this study were the post-trauma growth inventory (PTGI), and the ego strength psychological (PIES) and Healthy Boundaries Questionnaire (HB).

\section{- Ego Strength (PIES):}

The PIES consists of 64 items devised by Markstrom et al. (1997) to measure the eight ego strengths (hope, will, purpose, competence, fidelity, love, care, and wisdom) delineated by Erikson (1964), Erikson (1985).

Strom et al. (1997) as the authors of this questionnaire examined the validity and reliability of this questionnaire. They confirmed the face validity, content and structure of this questionnaire and 
medRxiv preprint doi: https://doi.org/10.1101/2021.05.11.21256630; this version posted May 11, 2021. The copyright holder for this preprint (which was not certified by peer review) is the author/funder, who has granted medRxiv a license to display the preprint in perpetuity.

All rights reserved. No reuse allowed without permission.

also reported it as 0.68 to evaluate its reliability from the Cronbach's alpha coefficient calculation method. Altafi (2009) also reported Cronbach's alpha of the list on an Iranian sample of 0.910 and the reliability of two scale halves of 0.77 .

\section{- Post-trauma Growth (PTG):}

Tedeschi and Calhoun (1995) developed the Post-Traumatic Growth Inventory (PTGI) to assess post-trauma growth and self-improvement a person undergoes. A 21-item scale built on the fivefactor model of Tedeschi, this inventory is one of the most valid and reliable resources for evaluating personal growth that follows a stressful encounter.

Each of the 21 items falls under one of the five factors and are scored accordingly. A summation of the scores indicates the level of post-traumatic growth. The advantage of this scale is that the categorization of scores according to the five factors is suggestive of which area of selfdevelopment is predominant in us and which area might be a little behind.

\section{- Healthy Boundaries (HB):}

20 QUESTION SELF ASSESSMENT FOR HEALTHY BOUNDARIES Copyright 1999. Dr. Jane Bolton, a marriage and family therapist, master results coach and contemporary psychoanalyst and is dedicated to supporting people in the fullest expression of their Authentic Selves. This includes Discovery, Understanding, Acceptance, Expression, and Empowerment of the Self.

\section{Executive method}

To collect information, after selecting samples, before giving questionnaires to diabetic patients A brief explanation of the purpose of the research, the need for their sincere cooperation to advance The objectives of the research and the way of answering the questions were given and it was stated that only your real attitude is the case It is an opinion and there is no right or wrong answer. It was also emphasized that there is no need to mention your name and identity not enough time was given to patients to answer the questions the type of bias was the order of questionnaires.

\section{Analysis Method}

In this research, considering that it is a correlation type of descriptive statistical methods (distribution table Frequency, central tendency indicators ...) as well as inferential statistical 
medRxiv preprint doi: https://doi.org/10.1101/2021.05.11.21256630; this version posted May 11, 2021. The copyright holder for this preprint (which was not certified by peer review) is the author/funder, who has granted medRxiv a license to display the preprint in perpetuity. All rights reserved. No reuse allowed without permission.

methods including correlation coefficient Pearson and multiple regressions were used simultaneously.

\section{Ethical Consideration}

1- The purpose of the study was explained to all participants.

2-Conscious consent was obtained from the participants.

3-Participants were assured that all data would remain confidential and that information would be kept confidential will be published collectively.

4- Participants were reassured about the optionality of participating in the study.

5-Participants were explained that they would be provided with research results if they wished. 6Participants were assured that the names of the participants would not be mentioned in all documents related to the research and its publications.

This study was approved in the Research Ethics Committee at the Research Institute of Shahid Beheshti University of Tehran with the code IR.SBU.Rec.1398.022

\section{RESULTS}

- Describing respondents based on demographic variables: Demographic information in this study includes gender, age, level of education, and peer housing. The following is the frequency and percentage of demographic variables in different sections. According to Table 1, 74\% of the total participants in the study (50 people) were "women" and 26\% were "men". The age of $44 \%$ was "less than 50 years old" and 56\% was "less than 50 years old". The education rate was 30\% for "diploma and sub-diploma", 4\% for "associate", $48 \%$ for "bachelor's degree", $16 \%$ for "master's degree" and 2\% for "doctorate and higher". $22 \%$ of people live "alone" and $28 \%$ live with "spouse", $10 \%$ with "children" and $40 \%$ with "spouse and children". 
Table 1: Description of respondents in terms of demographic variables

\begin{tabular}{|c|c|c|c|c|}
\multicolumn{1}{c|}{} & Variable & Frequency & Percent & Cumulative Percent \\
\hline \multirow{3}{*}{ Sex } & $\mathrm{F}$ & 37 & 74 & 74 \\
\cline { 2 - 5 } & $\mathrm{M}$ & 13 & 26 & 100 \\
\hline \multirow{3}{*}{ Age } & $<50$ & 22 & 44 & 44 \\
\cline { 2 - 5 } & $>50$ & 28 & 56 & 100 \\
\hline \multirow{4}{*}{ Educe } & $\mathrm{D}$ & 15 & 30 & 30 \\
\cline { 2 - 5 } & $\mathrm{As}$ & 2 & 4 & 34 \\
\cline { 2 - 5 } & $\mathrm{B}$ & 24 & 48 & 82 \\
\cline { 2 - 5 } & $\mathrm{Ms}$ & 8 & 16 & 98 \\
\hline \multirow{4}{*}{ live/w } & $\mathrm{PhD}$ & 1 & 2 & 100 \\
\cline { 2 - 5 } & $\mathrm{Alone}$ & 14 & 22 & 221 \\
\cline { 2 - 5 } & $\mathrm{Sp}$ & 5 & 10 & 50 \\
\cline { 2 - 5 } & $\mathrm{Ch}$ & 20 & 40 & 100 \\
\cline { 2 - 5 } & $\mathrm{S} \& \mathrm{Ch}$ & & 28 & \\
\hline
\end{tabular}

\section{- Descriptive statistics of research indicators:}

Table 2 lists the descriptive statistics of the research variables, including the number of respondents, the lowest value, the highest value, the mean, and the standard deviation. 
Table 2: Descriptive statistics of research variables

\begin{tabular}{|c|c|c|c|c|c|}
\hline & $\begin{array}{c}\mathrm{N} \\
\text { Statistic }\end{array}$ & $\begin{array}{l}\text { Minimum } \\
\text { Statistic }\end{array}$ & $\begin{array}{l}\text { Maximum } \\
\text { Statistic }\end{array}$ & $\begin{array}{c}\text { Mean } \\
\text { Statistic }\end{array}$ & $\begin{array}{c}\text { Std. Deviation } \\
\text { Statistic }\end{array}$ \\
\hline PTG & 50 & 41.00 & 100.00 & 73.2000 & 13.47560 \\
\hline PIS & 50 & 184.00 & 287.00 & 232.7200 & 31.39546 \\
\hline HB & 50 & 29.00 & 79.00 & 52.8200 & 13.00344 \\
\hline $\mathrm{HbA1c}$ & 50 & 6.00 & 9.00 & 7.3200 & .89625 \\
\hline Valid N (listwise) & 50 & & & & \\
\hline
\end{tabular}

To calculate the mean, we add the data of a variable and divide it by the number of observations. To calculate the standard deviation, we add the square of the distance of all values from the mean $\left(X_{i}-\bar{X}\right)^{2}$ and divide the result by the number of observations minus 1 and subtract from the resulting number.

Descriptive statistics are the properties of a data set; it describes the data. Descriptive statistics are used before formal inferences are made (Evans et al., 2004). The data set comes from a sample. A sample comes from the population.

Inferential statistics is defined as using the sample descriptive statistics to make an inference (estimation) of the population. The sample is the observation; the estimated population is the inferred value without observation.

\section{-Inferential analysis of the findings:}

The role of descriptive statistics is to collect, summarize, and describe quantitative information from samples or communities. But the researcher usually does not end his or her work by describing the information, but tries to generalize what he or she has learned from the sample 
medRxiv preprint doi: https://doi.org/10.1101/2021.05.11.21256630; this version posted May 11, 2021. The copyright holder for this preprint

(which was not certified by peer review) is the author/funder, who has granted medRxiv a license to display the preprint in perpetuity.

All rights reserved. No reuse allowed without permission.

group survey to larger similar groups. On the other hand, in most cases it is impossible to study all members of a community. Therefore, the researcher needs methods that can be used to generalize the results of the study of small groups to larger groups. The ways in which the characteristics of large groups are inferred based on the measurement of the same characteristics in small groups are called inferential statistics.

Statistical assumptions are claims about one or more populations that may be true or false. In other words, a statistical assumption is a claim or statement about the distribution of a population or the distribution parameter of a random variable. Statistical hypothesis is the starting point of the hypothesis test and it is basically difficult to perform a test without having statistical hypothesis. Statistical hypotheses are expressed as two types of null hypotheses (H0) and opposite assumptions (HA). The hypothesis that is tested in statistical tests is zero hypotheses, which always indicates that there is no difference. But the assumption is contrary to the same research hypothesis that can be directional or non-directional. Of course, the choice of directional hypothesis is not arbitrary and random, but research hypotheses can be developed if the previous theory or research provides evidence for it.

\section{- Questionnaire reliability review:}

Reliability is one of the technical characteristics of measuring instruments. This concept deals with the extent to which measuring tools produce the same results under the same conditions. Definitions for reliability include those defined by Abel and Frisbee (1989): "The correlation between a setoff scores and another set of scores in an equivalent test obtained independently of a group of subjects is."

Due to this, the range of reliability coefficient usually varies from zero (non-communication) to +1 (full communication). The reliability coefficient indicates the extent to which the measuring instrument measures the stability of the subject or his / her variable and temporary characteristics. Various methods are used to calculate the reliability coefficient of the measurement tool. Among them is Cronbach's alpha method, which is described below.

Cronbach's alpha is thus a function of the number of items in a test, the average covariance between pairs of items, and the variance of the total score. A value of zero for this coefficient indicates unreliability and +1 indicates complete reliability. As usual values greater than 0.7 for this coefficient can confirm the reliability of the questionnaire (Momeni and FaalQayyumi, 1396). 
medRxiv preprint doi: https://doi.org/10.1101/2021.05.11.21256630; this version posted May 11, 2021. The copyright holder for this preprint (which was not certified by peer review) is the author/funder, who has granted medRxiv a license to display the preprint in perpetuity.

All rights reserved. No reuse allowed without permission.

Table 3 Evaluation of the reliability of the questionnaire

\begin{tabular}{|c|c|c|}
\hline Variables & N of items & Cronbach's Alpha \\
\hline PTG & 21 & 0.827 \\
\hline PIES & 64 & 0.917 \\
\hline HB & 20 & 0.867 \\
\hline
\end{tabular}

Since the value of Cronbach's alpha coefficient in all questionnaire factors is greater than 0.7, Therefore, the factors of the questionnaire are at a very good level in terms of reliability. So, the reliability of the factors of the questionnaire and all the questions of the questionnaire is confirmed.

The aim of the study was to "predict blood glucose regulation (HbA1c) based on healthy boundaries, ego boundary and PTG in patients with diabetes". According of the study the normality test for the collected data should be performed to use the appropriate test to evaluate the hypotheses.

Normal distribution means that the distribution of variables on both sides of the mean is the same, so that the distribution diagram has a bell shape. The distribution of variables is normal. Parametric tests are used to test the hypotheses, otherwise non-parametric tests are used.

Table 4 Normality test results for research variables

\begin{tabular}{|c|c|c|c|c|r}
\hline Variables & df & $\begin{array}{c}\text { Statistic Kolmogorov- } \\
\text { Smirnov }\end{array}$ & $\begin{array}{c}\text { Sig. Kolmogorov- } \\
\text { Smirnov }\end{array}$ & Skewness & Kurtosis \\
\hline PTG & 50 & 0.079 & 0.2 & -0.393 & -0.207 \\
\hline PIES & 50 & 0.12 & 0.07 & 0.024 & -1.329 \\
\hline HB & 50 & 0.086 & 0.2 & 0.27 & -0.919 \\
\hline HbA1C & 50 & 0.139 & 0.016 & 0.476 & -0.766 \\
\hline
\end{tabular}

a. Lillifors Significance Correction 
medRxiv preprint doi: https://doi.org/10.1101/2021.05.11.21256630; this version posted May 11, 2021. The copyright holder for this preprint (which was not certified by peer review) is the author/funder, who has granted medRxiv a license to display the preprint in perpetuity.

All rights reserved. No reuse allowed without permission.

According to table 4, although the significance value of Kolmogorov-Smirnov test for some variables is less than 0.05 , the values of skewness and elongation for all research variables are in the range (2 and 2-). The normality of the data for these variables is confirmed. Therefore, we use parametric tests to test the research hypotheses. In total, the absolute value of the skewness and kurtosis coefficient greater than 2 indicates a violation of the normality of the data is problematic in data analysis and creates a serious problem he does. We also see in the quantitative diagrams of normal variables that all points are on a hypothetical line.

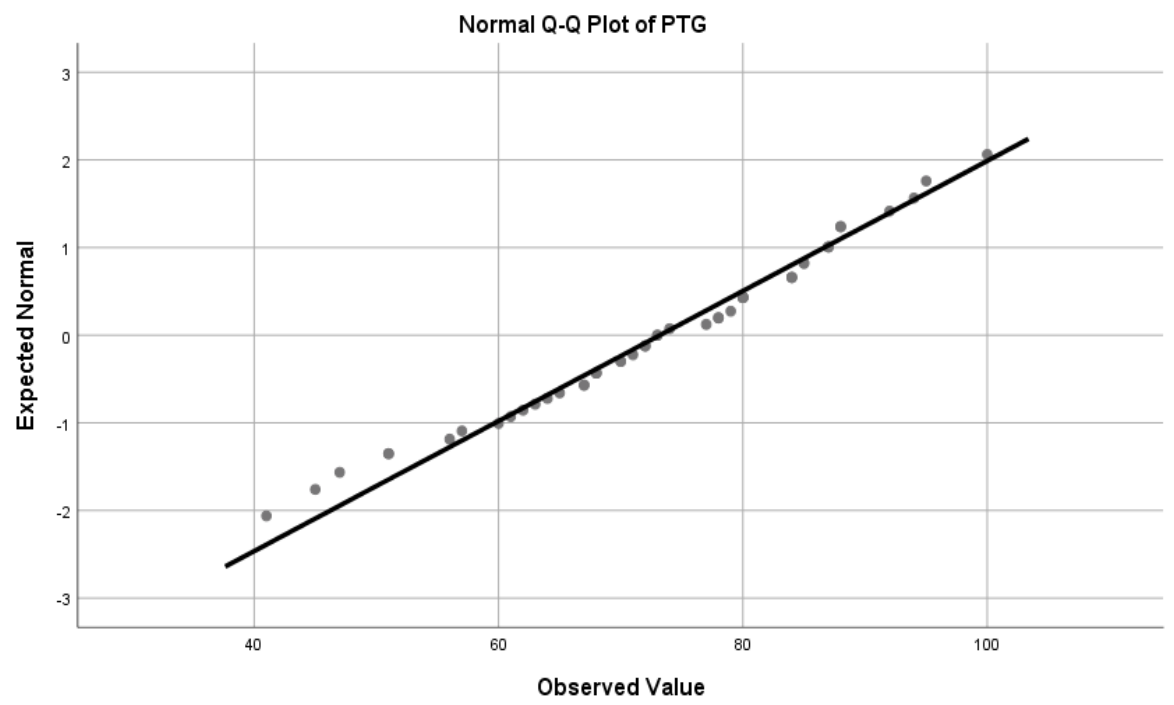

Figure 1 Quantitative diagram of normal quadratic growth variable Source: SPSS software output 
medRxiv preprint doi: https://doi.org/10.1101/2021.05.11.21256630; this version posted May 11, 2021. The copyright holder for this preprint (which was not certified by peer review) is the author/funder, who has granted medRxiv a license to display the preprint in perpetuity.

All rights reserved. No reuse allowed without permission.

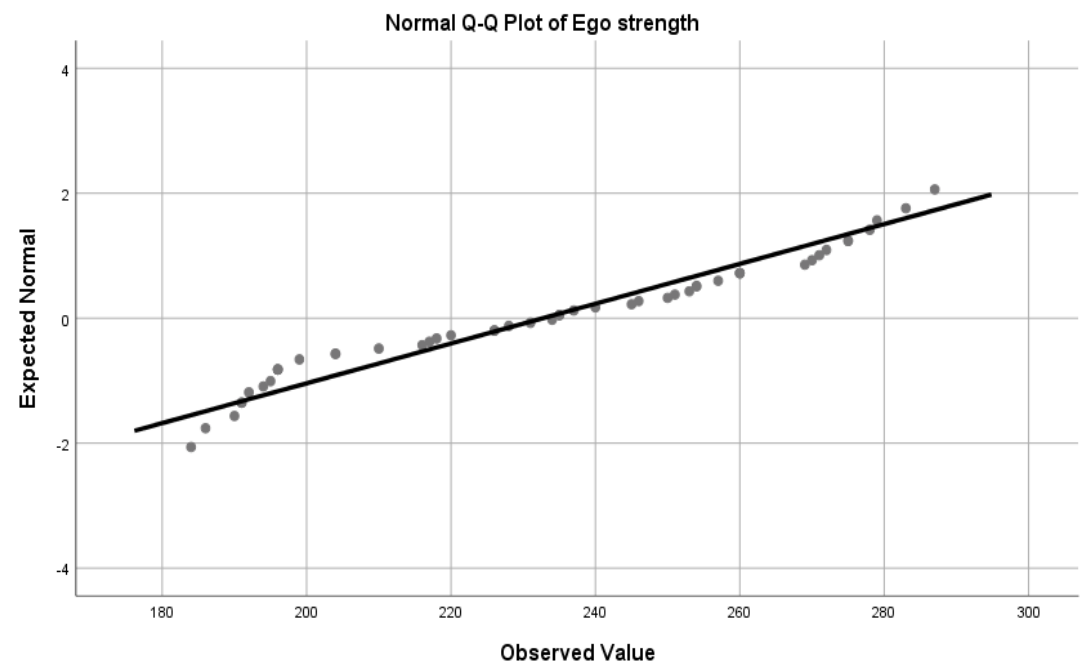

Figure 2 Graph of the normal multiplier of the ego strength variable Source: SPSS software output

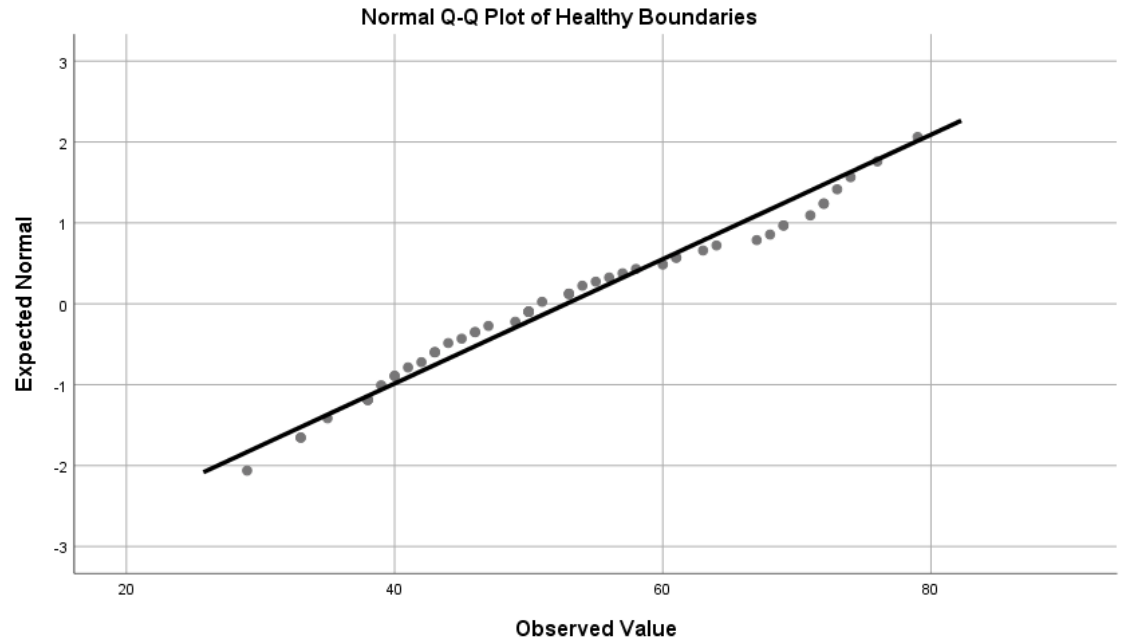


Figure 3 Normalmultiple diagram of a healthy bounedaries variable Source: SPSS software output

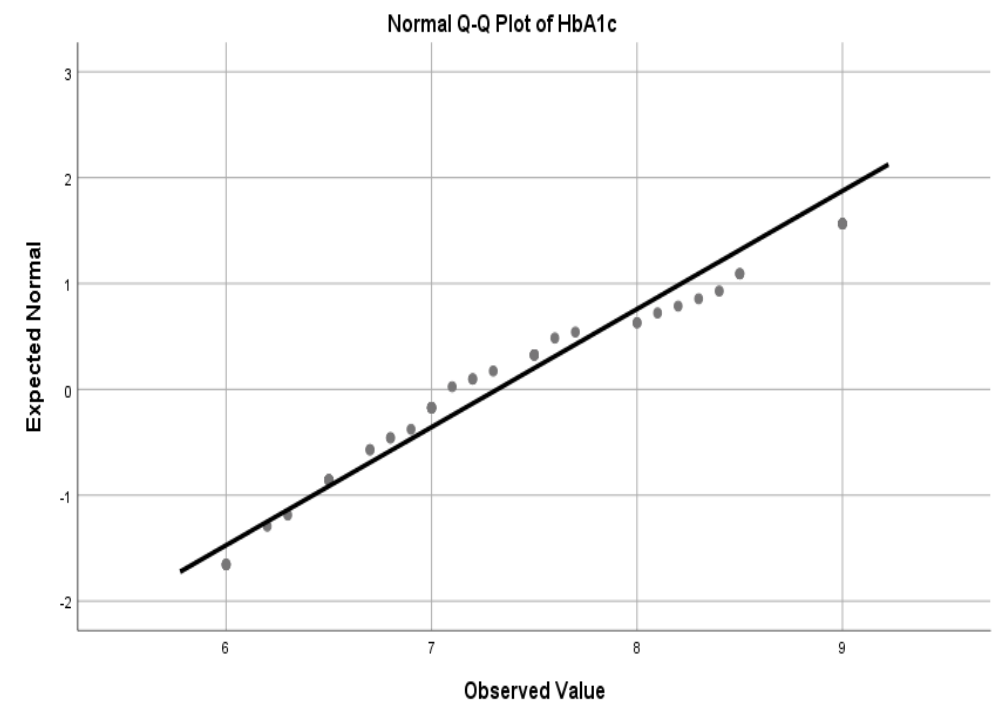

Figure 4 HbAlc Variable Normal Quantity Chart

Source: SPSS software output

\section{Correlation}

Most of the time, researchers want to know what the relationship is between two or more variables. Correlation is the measure of the linear relationship between variables. Note that two variables may be related; but this relationship is not linear. To find the correlation between the two variables, we decide which method to use according to the type of variable being studied. We use Pearson correlation when both of our variables are quantitative (continuous) and follow a normal distribution. If even one of the variables does not follow the normal distribution, we use Spearman correlation coefficient. The value of the correlation coefficient varies between -1 and +1 . A value of zero indicates that there is no linear relationship between the variables. According to the correlation matrix, if the significance value for the two indices is less than 0.05 , it means that the correlation coefficient between these two indices is significant and the two indices have a high correlation (Sadegh pourGildeh and Moradi, 2013). 
The partial correlation coefficient indicates the linear relationship between the two variables and the control of the effect of one or more other variables. In other words, the correlation coefficient of the two variables is in the presence of other variables. This correlation coefficient is most often used when we want to know which variable is more effective alone than other variables. In the present study, partial correlation was used to investigate the relationship between the dependent variable "HbA1c" and each of the independent variables "post-trauma growth", "ego strength" and "healthy boundaries". According to the correlation table, if the significance value for the two variables is less than 0.05 , it means that the correlation coefficient between these two variables is significant and the two variables have a high correlation (SadeghpourGildeh and Moradi, 2013).

Table 5 Correlation coefficients of research variables

\begin{tabular}{|llc|}
\hline Variable & & HbA1c \\
\hline PTG & Correlation & 0.338 \\
& Significance (2-tailed) & 0.019 \\
\hline \multirow{2}{*}{ PIES } & Correlation & 0.332 \\
& Significance (2-tailed) & 0.021 \\
\hline \multirow{2}{*}{ HB } & Correlation & 0.304 \\
& Significance (2-tailed) & 0.036 \\
\hline
\end{tabular}

According to table 5, the correlation coefficient between the dependent variable "HbA1c" and each of the independent variables "post-traumatic growth", "ego strength" and "healthy boundaries" is significant, because the significance value corresponding to these coefficients is less than 0.05 has been obtained. 
To test the research hypotheses, regression was used, which is the regression model of the research as follows:

$$
\mathrm{HbA} 1 \mathrm{c}=\beta_{0}+\beta_{1} * \mathrm{PTG}+\beta_{2} * \mathrm{PIS}+\beta_{3} * \mathrm{HB}+\varepsilon
$$

To examine the relationships between the research variables, the graph of the relationship between the dependent variable "HbA1c" and the independent variables of the research is as follows:

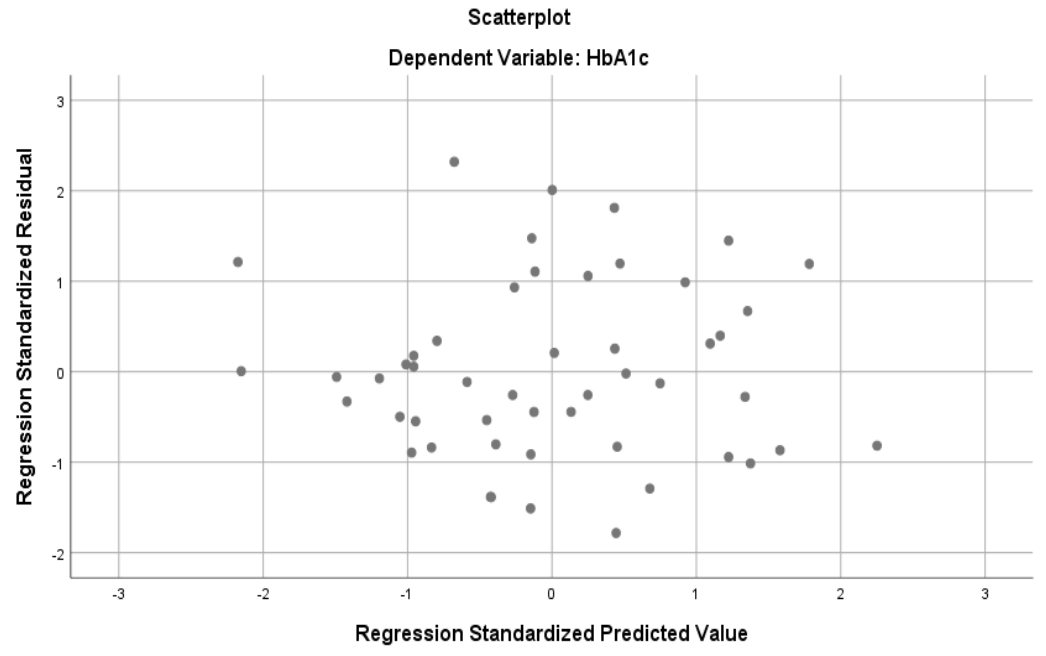

Figure 5 Residual distribution diagram and predicted values

Source: SPSS software output 


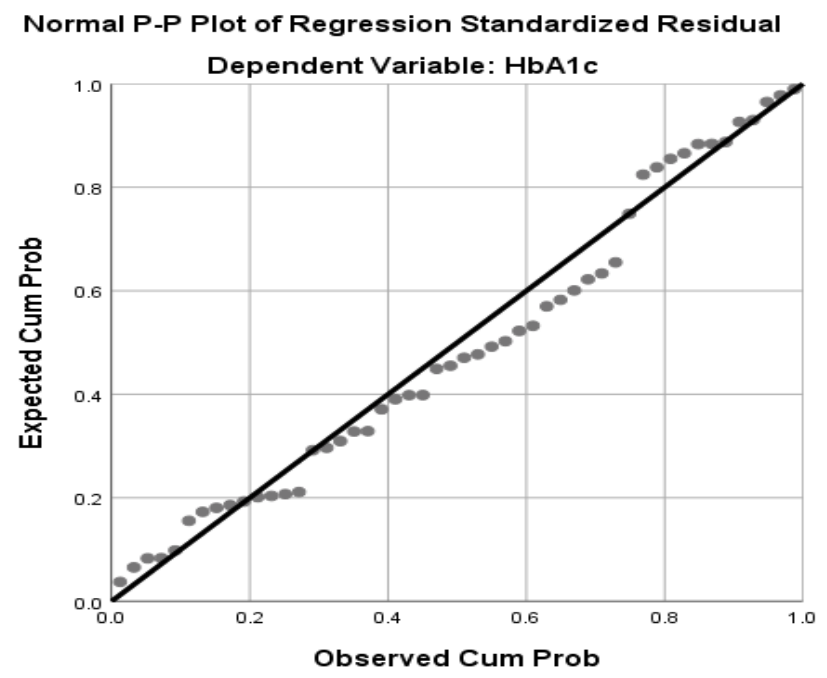

Figure 6 Normal multiple quadratic diagrams for residuals Source: SPSS software output

From the residual distribution graph and the predicted values (Figure 5), it can be seen that there is no definite relationship between the residuals and the predicted values, which is consistent with the assumption of linearity. Also, from the normal quadratic diagram for the residues, it can be seen that the residues are relatively normally distributed. Because according to this diagram, if all the points on the bisector are in the first quarter, then the remainder completely follows the normal distribution.

\section{- Watson Camera Test:}

After examining the regression assumptions, using multiple regressions, the predictive power of "HbA1c" was examined by each of the independent variables "post-traumatic growth", "ego strength" and "healthy boundaries". The regression model is as follows: 
medRxiv preprint doi: https://doi.org/10.1101/2021.05.11.21256630; this version posted May 11, 2021. The copyright holder for this preprint (which was not certified by peer review) is the author/funder, who has granted medRxiv a license to display the preprint in perpetuity.

All rights reserved. No reuse allowed without permission.

Table 6 Summary of standard regression model

\begin{tabular}{|c|c|c|c|}
\hline \multicolumn{4}{|c|}{ Variables Entered/Removed $^{a}$} \\
\hline Model & Variables Entered & Variables Removed & Method \\
\hline 1 & $\mathrm{HB}$ & & Enter \\
\hline & , PTG & & \\
\hline & PIES & & \\
\hline
\end{tabular}

a. Dependent Variable: HbA1c

b. All requested variables entered.

\begin{tabular}{|c|c|c|c|c|c|}
\hline \multicolumn{6}{|c|}{ Model Summary ${ }^{\text {b }}$} \\
\hline Model & $\mathrm{R}$ & R Square & $\begin{array}{l}\text { Adjusted R } \\
\text { Square } \\
\end{array}$ & $\begin{array}{c}\text { Std. Error of the } \\
\text { Estimate }\end{array}$ & Durbin-Watson \\
\hline 1 & $.428^{\mathrm{a}}$ & .183 & .130 & .83612 & 1.136 \\
\hline
\end{tabular}

a. Predictors: (Constant), PTG, PIES, HB

b. Dependent Variable: HbA1c

Table 7Significance test of standard regression model

\begin{tabular}{|c|c|c|c|c|c|c|}
\hline \multicolumn{7}{|c|}{ ANOVA $^{a}$} \\
\hline Model & & Sum of Squares & df & Mean Square & $\mathrm{F}$ & Sig. \\
\hline \multirow[t]{3}{*}{1} & Regression & 7.202 & 3 & 2.401 & 3.434 & $.024^{b}$ \\
\hline & Residual & 32.158 & 46 & .699 & & \\
\hline & Total & 39.360 & 49 & & & \\
\hline
\end{tabular}

a. Dependent Variable: HbA1c 
medRxiv preprint doi: https://doi.org/10.1101/2021.05.11.21256630; this version posted May 11, 2021. The copyright holder for this preprint (which was not certified by peer review) is the author/funder, who has granted medRxiv a license to display the preprint in perpetuity.

All rights reserved. No reuse allowed without permission.

Table 8Standard regression model coefficient

\section{Coefficients $^{\text {a }}$}

\begin{tabular}{|c|c|c|c|c|c|c|c|c|}
\hline \multirow{2}{*}{\multicolumn{2}{|c|}{ Model }} & \multicolumn{2}{|c|}{ Unstandardized Coefficients } & \multirow{2}{*}{$\begin{array}{c}\text { Standardized } \\
\text { Coefficients } \\
\text { Beta } \\
\end{array}$} & \multirow[b]{2}{*}{$\mathrm{t}$} & \multirow[b]{2}{*}{ Sig. } & \multicolumn{2}{|c|}{ Collinearity Statistics } \\
\hline & & $\mathrm{B}$ & Std. Error & & & & Tolerance & VIF \\
\hline \multirow[t]{4}{*}{1} & (Constant) & 5.342 & 1.336 & & 4.000 & .000 & & \\
\hline & PTG & -.023 & .009 & -.345 & -2.432 & .019 & .882 & 1.134 \\
\hline & PIES & .011 & .004 & .374 & 2.385 & .021 & .721 & 1.388 \\
\hline & $\mathrm{HB}$ & .022 & .010 & .322 & 2.163 & .036 & .803 & 1.245 \\
\hline
\end{tabular}

a. Dependent Variable: HbA1c

For the independent variables "post-traumatic growth", "ego strength" and "healthy boundaries", given the significant value associated with them, which is less than 0.05 , we can say that the independent variables "post-traumatic growth", "strength" Ego and healthy boundaries have a 
medRxiv preprint doi: https://doi.org/10.1101/2021.05.11.21256630; this version posted May 11, 2021. The copyright holder for this preprint (which was not certified by peer review) is the author/funder, who has granted medRxiv a license to display the preprint in perpetuity. All rights reserved. No reuse allowed without permission.

significant effect on the prediction of the dependent variable HbA1c. Finally, according to the results of Table 8, the regression model of the research is as follows:

\section{Discussion}

Because diabetes is very important, we need to identify people at risk for this disease.

Since, 'Ego boundaries' is an accepted concept in psychotherapeutic circles. Building on work by Freud, Federn could be seen as the father of the concept as it is currently accepted by psychology and psychiatry. Initially, ego boundaries form the point at which the infant's control of his world ceases (Federn, 1952b, p. 331).Since, A person without sufficient ego strength or healthy ego boundaries does not know what they want in life (E. Allers, personal communication, May 20, 2014), or if they do, they lack the assertiveness to attain their own goals, and are at the mercy of becoming subjugated to the more assertive wills of others, and according to the results of this study and the relationship between HbA1c blood sugar levels and ego strength, due to stress and insomnia can be concluded that ego strength is also effective in predicting and controlling HbA1c blood sugar levels.

A major cause of stress, overwhelm \& burnt-outedness is the habit of ignoring the yearnings of our own True Selves while saying "yes" to other people's requests (or demands) for our time, money, actions, even beliefs. In general, Healthy boundaries are those boundaries that are set to make sure mentally and emotionally you are stable.

As we know, Stress affects diabetes and blood sugar and Post-traumatic stress disorder (PTSD) is a psychiatric disorder that can occur in people who have experienced (directly or indirectly) or witnessed a traumatic event. It includes symptoms such as intrusion, avoidance, numbing, and hyper-arousal. Post-traumatic stress symptoms (PTSS) are often considered the most common negative psychological reactions in the aftermath of trauma.

In the other hand, Post-trauma growth (PTG) is defined as mastering a previously experienced trauma, perceiving benefits from it, and developing beyond the original level of psychological functioning (Tedeschi, Park, \& Calhoun, 1998). According to the result obtained from the third hypothesis, there is a positive and significant relationship between predict blood sugar regulation and on posttraumatic growth (PTG) in diabetic patients.

The findings indicate a significant correlation between hyperglycemia and health boundaries, ego strength and post-traumatic growth. This means that controlling and recognizing the boundaries of 
medRxiv preprint doi: https://doi.org/10.1101/2021.05.11.21256630; this version posted May 11, 2021. The copyright holder for this preprint (which was not certified by peer review) is the author/funder, who has granted medRxiv a license to display the preprint in perpetuity.

All rights reserved. No reuse allowed without permission.

mental health and post-traumatic emotions prevents high blood (HbA1c) sugar and Type 2 diabetes. It is recommended that future researchers:

- Review trauma in patients with diabetes what do they have, if it is the disease itself or other stressful events.

- Check the difference in HbA1c levels of the subjects before and after learning the boundaries, deeper research to determine whether the gene expression will change with teach the boundaries and stress control in the genome of an individual with a history of diabetes who may have inherited.

- Investigate the problems of diabetics economically, politically and socially.

- Also examine the neighborhood in which they live.

- Form groups to work on, people how to learn healthy boundaries and to dealing with stressful events and the formation of PTG houses in order to train post-traumatic growth to deal with high blood sugar and HbA1c.

-Organizing training classes for individuals, families and work environments.

- To deal with stressful events is suggested teaching life skills, strengthening the power of the ego and recognizing the boundaries of health to children.

\section{Conclusion:}

This study highlights the role and important of ego boundary, healthy boundaries and post trauma growth for researchers and psychologists. Since health boundaries, ego strength and posttraumatic growth play an essential role hyperglycemia. This leads us to realize that the effect of psychosocial health such as ego boundary, healthy boundaries and post trauma growth can be controlling and recognizing the boundaries of mental health and post-traumatic emotions prevents high blood (HbA1c) sugar and Type 2 diabetes. 
medRxiv preprint doi: https://doi.org/10.1101/2021.05.11.21256630; this version posted May 11, 2021. The copyright holder for this preprint (which was not certified by peer review) is the author/funder, who has granted medRxiv a license to display the preprint in perpetuity. All rights reserved. No reuse allowed without permission.

\section{Reference}

- Predicting long-term type 2 diabetes with support vector machine using oral glucose tolerance test Hasan T. Abbas, at el 2020Available:https://journals.plos.org/plosone/article?id=10.1371/journal.pone.0219636

- Mortality attributable to diabetes in 20-79 years old adults, 2019 estimates: Results from the International Diabetes Federation Diabetes Atlas, 9th edition Pouya Saeedi, at el 2020

- Dysfunctional attitudes, perfectionism, and models of vulnerability to depression, Gary P. Brown 2015

- Going beyond the Visible in Type 2 Diabetes Mellitus: Defense Mechanisms and Their Associations

With Depression and Health-Related Quality of Life (Gabriella Martino, at el 2020)

- Positive Psychological Interventions for Patients with Type 2 Diabetes: Rationale, Theoretical Model, and Intervention Development Jeff C Huffman 2015 available: https://pubmed.ncbi.nlm.nih.gov/26064980/

- The role of irrational health beliefs, health locus of control and health-oriented lifestyle in predicting the risk of diabetes (Fathabadi, at el 2018) available: PAYESH MARCH-APRIL 2018, Volume 17, Number 2; Page(s) 169 To 178.

- Karla S, Jena BN, Yeravdekar R. Emotional and Psychological Needs of People with Diabetes

- Depression, anxiety, and associated factors in patients with diabetes: evidence from the anxiety, depression, and personality traits in diabetes mellitus (ADAPT-DM) study Luke Sy-Cherng Woon

- How Much Do We Know about the Biopsychosocial Predictors of Glycemic Control? Age and Clinical Factors Predict Glycemic Control, but Psychological Factors Do Not Luke Sy-Cherng Woon

- Z. Wang, J. Xu, A cross-sectional study on risk factors of posttraumatic stress disorder in shidu parents of the sichuan earthquake, J. Child Fam. Stud. 25 (9) (2016) 1-9.

- Statistical analysis with SPSS and AMOS software, by Dr. Bahram SadeghpourGildeh and Vahab Moradi, Mazandaran University Press, Second Edition, 2013.

- Chen L, Magliano DJ, Zimmet PZ. The worldwide epidemiology of type 2 diabetes mellitus - present and future perspectives Nat Rev Endocrinol 2012;8(4):228-36.

-Murray CJ, Vos T, Lozano R, Naghavi M, Flaxman AD, Michaud C, et al. Disability-adjusted life years (DALYs) for 291 diseases and injuries in 21 regions, 1990-2010: a systematic analysis for the global burden of disease study 2010 Lancet. 2013; 380(9859):2197-223.

-Kumar SS, Houlden R. Ethnocultural diversity and the diabetes epidemic in Canada: a call to action. Can J Diab. 2005;29(2):845.

-Federation I, Atlas ID. International Diabetes Federation (IDF) diabetes atlas, 6th edn Brussels, Belgium: International Diabetes Federation. 2013.

-Nam Han Cho (chair) DWdc, Nita Forouhi, Leonor Guariguata, Ian Hambleton, Rui Li, Azeem Majeed, Jean Claude Mbanya, Pablo Aschner Montoya, Ayesha Motala, K.M. Venkat Narayan, Ambady Ramachandran, Wolfgang Rathmann, GojkaRoglic, Jonathan Shaw, Martin Silink, Ping Zhang. IDF Diabetes Atlas, Seventh Edition 2015.

- Guariguata L, Whiting D, Hambleton I, Beagley J, Linnenkamp U, Shaw J. Global estimates of diabetes prevalence for 2013 and projections for 2035. Diabetes Res Clin Pract 2014; 103(2):137-49.

- Hu FB. Globalization of diabetes the role of diet, lifestyle, and genes, Diabetes Care 2011; 34(6):1249-57.

- Amos AF, McCarty DJ, Zimmet P. The rising global burden of diabetes and its complications: estimates and projections to the year 2010. Diabet Med. 1997; 14(S5):S7-S85.

- Association AD Standards of medical care in diabetes - 2009 Diabetes Care, 2009; 32(Suppl 1):S13. 
- E ,Kiechl S , Mayr A , Zoppini G, Targher G, Bonadonna RC, et al . High-normal HbA1c is a strong predictor of type 2 diabetes in the general population. Diabetes Care 2011; 34: 1038- 40

- Colagiuri S, Borch-Johnsen K . DETECT-2: Early detection of type 2 diabetes and IGT Diabetes Voice 2003; 48: 11- 3

- SabanayagamC, Liew G, Tai ES, Shankar A, Lim SC, Subramaniam T, et al . Relationship between glycated haemoglobin and microvascular complications: Is there a natural cut-off point for the diagnosis of diabetes? Diabetologia 2009; 52: 1279-89

- Lu ZX, Walker KZ, O' Dea K, Sikaris KA, Shaw JE. HbA1c for screening and diagnosis of type 2 diabetes in routine clinical practice Diabetes Care 2010; 33: 817-9

- International Expert Committee, International expert committee report on the role of the A1c assay in the diagnosis of diabetes. Diabetes Care (2009; 32: 1327-34)

- Pradhan AD, Rifai N, BuringJE ,Ridker PM . Hemoglobin A1C predicts diabetes but not cardiovascular disease in nondiabetic women. Is J Med. 2007; 120: 720 - 27?

- DroumaguetC ,Balkau B, Simon D, Caces E, Tichet J, Charles MA, et al . Use of HbA1c in predicting progression to diabetes in French men and women: Data from an epidemiological study on the insulin resistance syndrome (DESIR). Diabetes Care 2006; 29: $1619-25$

- Joslin EP. The improvement in the treatment of diabetes mellitus. In: The treatment of diabetes mellitus. Philadelphia: Lea; 1917. p. 29. <https://archive.org/details/ treatmentofdiabe00josliala> [accessed 05.10.17].

- International Diabetes Federation. IDF Diabetes Atlas, $8^{\text {th }}$ ed. Brussels (Belgium): International Diabetes Federation; 2017. <https://www.idf.org/e-library/epidemiologyresearch/ diabetes-atlas.html> [accessed 20.11.17].

- World Health Organization. Global report on diabetes Geneva (Switzerland); World Health Organization; 2016 . <http://www.who.int/diabetes/global-report/en/> [accessed 05.10.17].

- Yates T, Khunti K. The diabetes mellitus tsunami: worse than the 'Spanish flu' pandemic? Nat Rev Endocrinol 2016; 12:377-8. [24] Yoon KH, Lee JH, Kim JW, Cho JH, Choi YH, Ko SH, et al. Epidemic obesity and type 2 diabetes in Asia. Lancet 2006; 368:1681-8.

- Nanditha A, Ma RC, Ramachandran A, Snehalatha C, Chan JC, Chia KS, et al. Diabetes in Asia and the Pacific: implications for the global epidemic. Diabetes Care 2016; 39:472-85.

- Zhang X, Geiss LS, Cheng YJ, Beckles GL, Gregg EW, Kahn HS.The missed patient with diabetes: how access to health care affectsthe detection of diabetes. Diabetes Care 2008; 31: 1748-53.

- Knowler WC, Barrett-Connor E, Fowler SE, et al. Reduction in theincidence of type 2 diabetes with lifestyle intervention ormetformin. N Engl J Med 2002; 346: 393-403.

- Farzadfar F, Murray CJ, Gakidou E, et al. Eff ectiveness of diabetesand hypertension management by rural primary healthcareworkers (Behvarz workers) in Iran: a nationally representativeobservational study. Lancet 2012; 379: 47-54.

- Gregg EW, Albright AL. The public health response to diabetes-twosteps forward, one step back. JAMA 2009; 301: 1596-98.

- Ramachandran A, Snehalatha C, Mary S, et al. The Indian DiabetesPrevention Programme shows that lifestyle modifi cation andmetformin prevent type 2 diabetes in Asian Indian subjects withimpaired glucose tolerance (IDPP-1). Diabetologia2006; 49: 289-97.

- Saaristo T, Moilanen L, Korpi-Hyovalti E, et al. Lifestyle interventionfor prevention of type 2 diabetes in primary health care: one-yearfollow-up of the Finnish National Diabetes Prevention Program(FIN-D2D). Diabetes Care 2010; 33: $2146-51$.

- DePue JD, Dunsiger S, Seiden AD, et al. Nurse-community healthworker team improves diabetes care in American Samoa: results ofa randomized controlled trial. Diabetes Care 2013; 36: 1947-53.

- Narayan KM, Echouff o-Tcheugui JB, Mohan V, Ali MK. Analysis \&commentary: global prevention and control of Type 2 diabetes will require paradigm shifts in policies within and among countries.Health Aff (Millwood) 2012; 31: 84-92

- Li C, Ford ES, Strine TW, and Mokdad AH: Prevalence of depression among U.S. adults with diabetes: findings from the 2006 behavioral risk factor surveillance system. Diabetes Care 2008, 31(1):105-107. 
- Ali S, Stone MA, Peters JL, Davies MJ, Khunti K: The prevalence of co-morbid depression in adults with Type 2 diabetes: a systematic review and meta-analysis. Diabet Med 2006, 23(11):1165-1173.

- Katon W, Von Korff M, Ciechanowski P, Russo J, Lin E, Simon G, Ludman E, Walker E, Bush T, and Young B: Behavioral and clinical factors associated with depression among individuals with diabetes. Diabetes Care 2004, 27(4):914-920.

- Katon WJ, Simon G, Russo J, Von Korff M, Lin EHB, Ludman E, Ciechanowski P, Bush T: Quality of depression care in a population-based sample of patients with diabetes and major depression. Med Care 2004, 42(12):1222-1229.

"Boundaries: Psychological Boundaries - Healthy Boundaries". www.guidetopsychology.com.

- Graham, Michael C. (2014). Facts of Life: ten issues of contentment. Outskirts Press. p. 159 ISBN 978-1-4787-2259-5

Rogers, Vanessa (2010). Working with Young Men. pp. 80, 161

- Johnson, R. Skip. "Setting Boundaries and Setting Limits". BPDFamily.com. Retrieved 10 June 2014.

- Lundberg, G. B.; Lundberg, J. S. (2000). I Don't Have to Make Everything All Better. p. 13. ISBN 978-0-670-88485-8.

- Porter-O'Grady, Timothy; Malloch, Kathy (2003). Quantum Leadership. p. 135.

- Katherine, Anne (2000). Where to Draw the Line: How to Set Healthy Boundaries Every Day. pp. 16-25. - Whitfield, Charles L., M.D. (2010). Boundaries and Relationships: Knowing, Protecting and Enjoying the Self (2 ed.). HCIBooks. ISBN 978-1-55874-259-8.

Katherine, Anne (1994). Boundaries: Where You End and I Begin. Hazelden. p. 5. ISBN 978-1-56838-030-8.

- Townsend, John, PhD; Cloud, Henry, PhD (1 November 1992). Boundaries: When to Say Yes, How to Say No to Take Control of Your Life. Nashville: HarperCollins Christian Publishing. p. 245. ISBN 978-0-310-58590-9.

- E. H. Erikson, Insight and Responsibility, Lectures onThe Ethical Implications of Psychoanalytic Insight, W. W. Norton, New York, NY, USA, 1964.

- E. H. Erikson, the Life Cycle Completed: A Review, Norton, New York, NY, USA, 1982.

- C.A.Markstrom, V.M. Sabino, B. J. Turner, and R. C. Berman, "The psychosocial inventory of ego strengths: development and validation of a new Eriksonian measure," Journal of Youth and Adolescence, vol. 26, no. 6, pp. 705-732, 1997.

- C. A. Markstrom and S. K. Marshall, "The psychosocial inventory of ego strengths: examination of theory and psychometric properties," Journal of Adolescence, vol. 30, no. 1, pp.63-79, 2007.

- Adorno, T., Frenkel-Brunswik, E., Levinson, D. \& Sanford, R. (1950). The authoritarian personality. New York: Harper. Anzieu, D. (1987). Le Moi peau. Paris: Monod Press. Armor, D. (1973-4). Theta reliability and factor scaling. In H. Costner, Ed., Sociological Methodology, San Francisco: Jossey-Bass.

- Barbuto, J., \& Plummer, B. (1998). Mental boundaries as a new dimension of personality: a comparison of Hartmann's boundaries in the mind and Jung's psychological types. Journal of Social Behavior and Personality, 13, 421-436.

- Barbuto, J. \& Plummer, B. (2000). mental boundaries and Jung's psychological types: a profile analysis. Journal of Psychological Type, 54, 17-21.

- Barrett, D. (1989). The relationship of thin vs. thick boundaries to hypnotic susceptibility. Paper presented at the meetings of the Eastern Psychological Association. Boston, MA. April, 1989.

Bell, M., Billington, R., \& Becker, B. (1986). A scale for the assessment of object relations: reliability, validity, and factorial invariance. Journal of Clinical Psychology, 42, 733-741.

- Bem, D., \&Honorton, C. (1994). Does Psi exist? Replicable evidence for an anomalous process of information transfer. Psychological Bulletin. 115, 4-27.

- Bevis, J. (1986) Connectedness versus separateness: understanding male/female differences in self and relationship. (Unpublished doctoral dissertation, Boston University).

- Blatt, S., \&Ritzler, B. (1974). Thought disorder and boundary disturbance in psychosis. Journal of Consulting and Clinical Psychology, 42, 370-381.

- Broadbent, D. (1971). William James Lectures. In Broadbent, D. (1973) In Defense of Empirical Psychology. London: Methuen. 
- Costa, P., \& McCrae, R. (1992). Revised NEO Personality Inventory (NEO-PI_R) and NEO Five-Factor Inventory (NEO-FFI) Professional Manual. Odessa, FL: Psychological Assessment Resources.

- Cowen, D. \& Levin, R. (1995). The use of the Hartmann Boundary Questionnaire with an adolescent population. Dreaming, 5, 105-114.

- Earle, J. (1992) Social desirability and thin boundaries. Unpublished manuscript.

- Freud, S. (1923). The ego and the id. In The st\&ard edition of the complete psychological works of Sigmund Freud, vol. 19 (pp. 3-66). London: Hogarth Press.

- Funkhauser, A, Würmle, O., Cornu, C., \&Bahro, M. (2001). Dream life \& intrapsychic boundaries in the elderly. Dreaming,11, 83-88.

- Galvin, F. (1993). The effect of lucid dream training upon the frequency \& severity of nightmares Unpublished Doctoral dissertation, Boston University..

- Gardner, R., Holzman, P., Klein, G., Linton, H., \& Spence, D. (1959). Cognitive control: a study of individual consistencies in cognitive behavior. Psychological Issues, Monograph 4. New York: International Universities Press.

- Garg, M., \& Hartmann, E. (1993) Neuropsychology of persons with thick or thin boundaries. Unpublished manuscript..Gsell, P. (1971). Rodin on Art. New York: Horizon Press.

- Harrison, R., Hartmann, E., \& Bevis, J. (1989) The Hartmann Boundary Questionnaire: a measure of thin \& thick boundaries. Manuscript submitted for publication.

- Hartmann, E. (1989). Boundaries of dreams, boundaries of dreamers: thin \& thick boundaries as a new personality dimension. Psychiaric Journal of the University of Ottawa, 14, 557-560.

- Hartmann, E. (1991) Boundaries in the Mind, New York: Basic Books.

- Hartmann, E. (1992). Boundaries in the mind: boundary structure related to sleep \& sleep disorders. Sleep Research, $21,126$.

- Hartmann, E. (1997). The concept of boundaries in counseling \& psychotherapy. British Journal of Guidance\& Counseling, $25,147-162$

- Hartmann, E. (1998). Dreams \& Nightmares. New York: Plenum Press (1998), Perseus (2000).

- Hartmann, E., Baekel\&, F., \& Zwilling, G. (1972). Psychological differences between long \& short sleepers. Arch Gen Psychiat, 26, 463-468.

- Hartmann, E., Harrison, R., Bevis, J., Hurwitz, I., Holevas, A., \&Dawani, H. (1987). The Boundary Questionnaire: a measure of thin \& thick boundaries derived from work with nightmare sufferers. Sleep Research, 16, 274.

- Hartmann, E. Elkin, R., \& Garg, M.(1991). Personality \& Dreaming: the dreams of people with very thick or very thin boundaries. Dreaming 1, 311-324.

- Hartmann, E., \&Zborowski, M. (2001). Dreams: correlates of the Contextualizing Image. Sleep, 24S, A174.

- Hartmann, E., Zborowski, M., McNamara, P., Rosen, R., \& Grace, N. (1999). Contextualizing images in dreams: relationship to the emotional state of the dreamer. Sleep, $22 S, 131$.

- James, W. (1907). Pragmatism: A New Name for Some Old Ways of Thinking. New York: Washington Square Press, 1983.

- Jawer, M. (2001) The Emotional Gateway: The Dynamics of Feeling \& their Link to Paranormal Perception. Manuscript submitted for publication.

- Krippner, S., Wickramasekera, I., Wickramasekera, J., \& Winstead, C. (1998). The Ramtha phenomenon: psychological, phenomenological, \& geomagnetic data. The Journal of the American Society for Psychical Research, 92, 1-24.

- Kunzendorf, R., \& Maurer, J. (1988-89). Hypnotic attenutation of the 'boundaries' between emotional, visual, \& auditory sensations. Imagination, Cognition \& Personality, 8(3), 225-234.

- Kunzendorf, R., Hartmann, E., Cohen, R., \& Cutler, J. (1997). Bizarreness of the dreams and daydreams reported by individuals with thin and thick boundaries. Dreaming, 7, 265-271.

- Landis, B. (1970). Ego boundaries. Psychological Issues, 6(4), Monograph \#24. New York: International Universities Press. 
- Lange, R., Thalbourne, M., Houran, J., \& Storm, L. (2000). The revised Transliminality Scale: reliability and validity data from a Rasch top-down purification procedure. Consciousness and Cognition,9, 591-617.

- Levin, R., Galen, J. \&Zywiak, B. (1991) Nightmares, Boundaries, and Creativity. Dreaming 1, 63-74.

- Levin, R., \& Fireman, G. (1993). Psychoanalytic studies on the experience of schizophrenia. In Masling, J. \& Bornstein, R., eds., Psychoanalytic Perspectives on Psychopathology (pp. 139-189). Washington, D.C.: APA Press.

- Levin,R., Gilmartin, L., \&Lamontanaro, L. (1998-99). Cognitive style and perception: the relationship of boundary thinness to visual-spatial processing in dreaming and waking thought. Imagination, cognition, and personality, 18(1), 25-41.

- McCrae, R. (1994). Openness to experience: expanding the boundaries of factor V. European Journal of Personality, 8, 251272.

- Schredl, M., Kleinferchner, P., \&Gell, T. (1996). Dreaming and personality: thick vs. thin boundaries. Dreaming, 6, $219-223$.

- Thalbourne, M. (1996). Belief in life after death: psychological origins and influences. Personality and Individual Differences, 21, 1043-1045.

- Watson, R. (July, 1985). Phasic integrated potentials and ego boundary deficit. Paper presented to a joint meeting of the Sleep Research Society and the Association of Sleep Disorders Centers. Seattle, Washington.

- Zborowski, M., McNamara, P., Hartmann, E., Murphy, M., \&Mattle, L. (1998) Boundary structure related to sleep measures and to dream content. Sleep, $21 \mathrm{~S}, 284$.

- Markstrom, C. A., \&Kalmanir, H. M. (2001) Linkages between the psychosocial stages of identity and intimacy and the ego strengths of fidelity and love. Identity: An International Journal of Theory and Research, 1, 179-196.

Erikson, E. H. (1985). The life cycle completed. New York: Norton.

- B. Tang, Q. Chen, X. Chen, D. Glik, X. Liu, Y. Liu, et al., Earthquake-related injuries among survivors: a systematic review and quantitative synthesis of the literature, Int. J. Disaster Risk Reduct. 21 (2017) 159-167.

- S. Akerkar, M. Fordham, Gender, place and mental health recovery in disasters: addressing issues of equality and difference, Int. J. Disaster Risk Reduct. 23 (2017) 218-230.

- N.A.S. Rna, A.A.M. Thabet, P.V.M. Frcpsych, Exposure to war traumatic experiences, posttraumatic stress disorder and posttraumatic growth among nurses in gaza, J. Psychiatr. Ment. Health Nurs. 22 (10) (2015) 749-755.

- L. Ying, C. Chen, C. Lin, E. Greenberger, X. Wu, L. Jiang, The relationship between posttraumatic stress symptoms and suicide ideation among child survivors following the wenchuan earthquake, Suicide Life-Threat. Behav. 45 (2) (2015) $230-242$.

- R.G. Tedeschi, L.G. Calhoun, Posttraumatic growth: conceptual foundations and empirical evidence, Psychol. Inq. 15 (1) (2004) $1-18$.

- S.C. Danhauer, G. Russell, L.D. Case, S.J. Sohl, R.G. Tedeschi, E.L. Addington, et al., Trajectories of posttraumatic growth and associated characteristics in women with breast cancer, Ann. Behav. Med. 49 (5) (2015) 650-659.

- J.Y. Zhang, Y.Q. Zhou, Z.W. Feng, Y.N. Fan, G.C. Zeng, L. Wei, Randomized controlled trial of mindfulness-based stress reduction (mbsr) on posttraumatic growth of chinese breast cancer survivors, Psychol. Health Med. 22 (1) (2017) 94-109.

J. Yi, B. Zebrack, A.M. Kim, M. Cousino, Posttraumatic growth outcomes and their correlates among young adult survivors of childhood cancer, J. Pediatr. Psychol. 40 (9) (2015) 981-991.

- V. Bianchini, L. Giusti, A. Salza, V. Cofini, M.G. Cifone, M. Casacchia, et al., Moderate depression promotes posttraumatic growth (ptg): a young population survey 2 years after the 2009 l'aquila earthquake, Clin. Pract. Epidemiol. Ment. Health 13 (1) (2017) 10-19.

- P.A. Linley, S. Joseph, Positive change following trauma and adversity: a review, J. Trauma. Stress 17 (1) (2004) 11-21.

I. Bluvstein, L. Moravchick, D. Sheps, S. Schreiber, M. Bloch, Posttraumatic growth, posttraumatic stress symptoms and mental health among coronary heart disease survivors, J. Clin. Psychol. Med. Settings 20 (2) (2013) 164-172.

- C. Ramos, I. Leal, Posttraumatic growth in the aftermath of trauma: a literature review about related factors and application contexts, Psychol. Community Health 2 (1) (2013) 43-54. 
medRxiv preprint doi: https://doi.org/10.1101/2021.05.11.21256630; this version posted May 11, 2021. The copyright holder for this preprint (which was not certified by peer review) is the author/funder, who has granted medRxiv a license to display the preprint in perpetuity. All rights reserved. No reuse allowed without permission.

- Z. Bromand, S. TemurErman, R. Yesil, A. Heredia Montesinos, M.C. Aichberger, D. Kleiber, et al., Mental health of turkish women in germany: resilience and risk factors, Eur. Psychiatry 27 (2) (2012) 17-21.

- Banik, G., \&Gajdosova, B. (2014). Positive changes following cancer: Posttraumatic growth in the context of other factors in patients with cancer. Supportive care in cancer: Official journal of theMultinational Association of Supportive Care in Cancer, 22(8), 2023-2029.

- Kampman H, Hefferon K, Wilson M, Beale J. (2015). "I Can Do Things Now That People Thought Were Impossible, Actually, Things That I Thought Were Impossible": A Meta-Synthesis of the Qualitative Findings on Posttraumatic Growth and Severe Physical Injury. Can Psychol, 53 (3): 283 294.

- Physical post traumatic growth inventory PLOS ONE | https://doi.org/10.1371/journal.pone.0195992 April 27, 2018 16 / 17

- Bevan AL, Maxfield M, Bultmann MN. (2014). The effects of age and death awareness on intentions for healthy behaviors'. Psychol Health, 29(4): 405 \pm 21 . https://doi.org/10.1080/08870446.2013.859258 PMID: 24274088 